\title{
Drilling the Crust at Mid-Ocean Ridges An "In Depth" Perspective
}

\section{BY BENOÎT ILDEFONSE, PETER A. RONA, AND DONNA BLACKMAN}

In April 1961, $13.5 \mathrm{~m}$ of basalts were drilled off Guadalupe Island about $240 \mathrm{~km}$ west of Mexico's Baja California, together with a few hundred meters of Miocene sediments, in about $3500 \mathrm{~m}$ of water. This first-time exploit, reported by John Steinbeck for Life magazine, aimed to be the test phase for the considerably more ambitious Mohole project, whose objective was to drill through the oceanic crust down to Earth's mantle (Lill and Bascom, 1959; Bascom, 1961). Born in the late 1950s, the Mohole project unfortunately ended in muddy waters and was terminated by the United States Congress in 1965 (Shor, 1985; Greenberg, 1971). Undeterred, the scientific community rallied again to launch the Deep Sea Drilling Project (DSDP) in 1968, followed by the Ocean Drilling Program (ODP) in 1985, and the Integrated Ocean Drilling Program (IODP) in 2003. These programs have provided solutions to some of the most pressing and interesting problems in ocean and earth science (see, for example, Oceanography 19-4, December 2006).
In the early 1970s, almost 15 years after the first Mohole attempt, attendees of a Penrose field conference (Conference Participants, 1972) formulated the concept of a layered oceanic crust composed of lavas, underlain by sheeted dikes, then gabbros (corresponding to the seismic layers $2 \mathrm{~A}, 2 \mathrm{~B}$, and 3, respectively), which themselves overlay mantle peridotites. Deep drilling into the oceanic crust would provide the ground truth for the Penrose model; the flame of the Mohole project still burned. This article draws from results of more than 30 years of ocean drilling at mid-ocean ridges or in older igneous oceanic crust and briefly reviews some important milestones that improved understanding of crustalaccretion processes at mid-ocean ridges. Figure 1 shows the locations of the numerous DSDP, ODP, and IODP expeditions to which we refer; Table 1 lists site locations. 


\section{DSDP: THE EARLY YEARS}

The first confirmation that oceanic layer 2A was made of basaltic flows and pillow lavas came in 1973 from drilling on the Nazca Plate (DSDP Leg 34) in the eastern Pacific Ocean, and on the western flank of the Mid-Atlantic Ridge, south of the Azores Plateau (DSDP Leg 36). Deep drilling of the oceanic basement was then attempted at several sites in the North Atlantic Ocean (e.g., DSDP Legs 45, 46, 51 , and 52). Core recovery, although good enough to allow high-quality scientific investigation of the samples, was limited, typically less than 40 percent. Deep penetration of the crust was pre- cluded by poor drilling conditions in basalts at depth. The most spectacular failure was when the derrick of the drilling vessel Glomar Challenger bent during DSDP Leg 46 as the hole reached $255 \mathrm{~m}$ in basaltic crust at Site 396.

DSDP boreholes yielded the first indications that the Penrose model cannot

Table 1. Site Numbers, Locations, and Main Characteristics

\begin{tabular}{|c|c|c|c|c|}
\hline Leg/Exp. * & Year & Site \# & Location & Comment \\
\hline 34 & $1973 / 74$ & $319-321$ & $\begin{array}{l}\text { Eastern Pacific, Nazca plate } \\
13.02^{\circ} \mathrm{S}, 101.52^{\circ} \mathrm{W} \\
9.01^{\circ} \mathrm{S}, 83.53^{\circ} \mathrm{W} \\
12.02^{\circ} \mathrm{S}, 81.90^{\circ} \mathrm{W}\end{array}$ & Early drilling in basalt \\
\hline 37 & 1974 & $332-335$ & $\begin{array}{l}\text { MAR } \\
36.88^{\circ} \mathrm{N}, 33.64^{\circ} \mathrm{W} \\
36.84^{\circ} \mathrm{N}, 33.68^{\circ} \mathrm{W} \\
37.03^{\circ} \mathrm{N}, 34.41^{\circ} \mathrm{W} \\
37.29^{\circ} \mathrm{N}, 35.20^{\circ} \mathrm{W}\end{array}$ & $\begin{array}{l}\text { Early drilling in basalt at the Mid-Atlantic Ridge (MAR); gabbro and } \\
\text { serpentinized peridotite in Hole } 334\end{array}$ \\
\hline 45 & $1975 / 76$ & 395 & $\begin{array}{l}\text { MAR } \\
22.76^{\circ} \mathrm{N}, 46.08^{\circ} \mathrm{W}\end{array}$ & $\begin{array}{l}\text { Basalts, a few gabbro and serpentinized peridotite cobbles in } 576.5-\mathrm{m} \text { - } \\
\text { deep Hole } 395 \mathrm{~A}\end{array}$ \\
\hline 46 & 1976 & 396 & $\begin{array}{l}\text { MAR } \\
22.99^{\circ} \mathrm{N} 43.51^{\circ} \mathrm{W}\end{array}$ & Drilled $255 \mathrm{~m}$ in basalt \\
\hline $51,52,53$ & 1976/77 & 417,418 & $\begin{array}{l}\text { Northern Atlantic } \\
25.11^{\circ} \mathrm{N}, 68.04^{\circ} \mathrm{W} \\
25.03^{\circ} \mathrm{N}, 68.06^{\circ} \mathrm{W}\end{array}$ & $\begin{array}{l}108 \text { million year old basaltic upper crust, better recovery ( } ~ 70 \text { percent); } \\
\text { massive flows and pillow lava }\end{array}$ \\
\hline 82 & 1981 & $\begin{array}{l}556,558 \\
560\end{array}$ & $\begin{array}{l}\text { MAR } \\
38.94^{\circ} \mathrm{N}, 34.68^{\circ} \mathrm{W} \\
37.77^{\circ} \mathrm{N}, 37.34^{\circ} \mathrm{W} \\
34.72^{\circ} \mathrm{N}, 38.84^{\circ} \mathrm{W}\end{array}$ & $\begin{array}{l}\text { A few tens of meters of metamorphosed gabbro and serpentinized } \\
\text { peridotite }\end{array}$ \\
\hline 109 & 1986 & 670 & $\begin{array}{l}\text { MAR } \\
23.17^{\circ} \mathrm{N}, 45.03^{\circ} \mathrm{W}\end{array}$ & First intentionally drilled peridotite; 92.5 -m-deep hole, 7 percent recovery \\
\hline 139 & 1991 & 856 & $\begin{array}{l}\text { Northern Juan de Fuca Ridge } \\
48.44^{\circ} \mathrm{N}, 128.7^{\circ} \mathrm{W}\end{array}$ & $\begin{array}{l}8 \text { holes to a maximum of } 122 \text { meters below seafloor through inactive } \\
\text { massive sulfide body and sediment into a basalt sill (Bent hill) }\end{array}$ \\
\hline 147 & $1992 / 93$ & $894-895$ & $\begin{array}{l}\text { Eastern Pacific, Hess Deep } \\
2.30^{\circ} \mathrm{N}, 101.5^{\circ} \mathrm{W} \\
2.28^{\circ} \mathrm{N}, 101.4^{\circ} \mathrm{W}\end{array}$ & $\begin{array}{l}\text { Upper mantle peridotites and upper crust gabbros in fast-spreading EPR } \\
\text { crust }\end{array}$ \\
\hline $\begin{array}{l}69,70,83 \\
111,137 \\
140,148\end{array}$ & 1979-93 & 504 & $\begin{array}{l}\text { Eastern Pacific, } \\
\text { Guatemala Basin } \\
1.23^{\circ} \mathrm{N}, 83.73^{\circ} \mathrm{W}\end{array}$ & $\begin{array}{l}504 \mathrm{~B} \text { is the deepest scientific oceanic borehole (drilled to } 2111 \text { meters } \\
\text { below seafloor); upper rocks are basaltic; 5.9-million-year-old } \\
\text { intermediate-spreading crust }\end{array}$ \\
\hline 153 & $1993 / 94$ & $920-924$ & $\begin{array}{l}\text { MAR Kane Fracture Zone area } \\
23.34^{\circ} \mathrm{N}, 45.02^{\circ} \mathrm{W} \\
23.54^{\circ} \mathrm{N}, 45.03^{\circ} \mathrm{W} \\
23.52^{\circ} \mathrm{N}, 45.03^{\circ} \mathrm{W} \\
23.54^{\circ} \mathrm{N}, 45.01^{\circ} \mathrm{W}\end{array}$ & $\begin{array}{l}\text { 200-m-deep Hole 920D in peridotites ( } 57 \text { percent recovery); ten short } \\
\text { holes (a few tens of meters) drilled in gabbros in the inside corner high } \\
\text { south of the Kane Fracture Zone }\end{array}$ \\
\hline
\end{tabular}


be applied along the entire mid-ocean ridge system and that the oceanic crust is much more heterogeneous, at least locally. At Site 334 (DSDP Leg 37), gabbros and serpentinized (water-altered) peridotites were recovered at shallow depth, directly underlying 50 meters of basalts; several kilometers of Penrose- style crust appeared to be missing. During DSDP Leg 45, on the western flank of the Mid-Atlantic Ridge south of the
Kane Fracture Zone, a few gabbro cobbles were recovered from the bottom of a 588-m-deep hole in sediments and

\section{BENOÎT ILDEFONSE (benoit.ildefonse@univ-montp2.fr) is CNRS Researcher, Géosciences}

Montpellier, Université Montpellier 2, Montpellier, France. PETER A. RONA is Professor, Institute of Marine and Coastal Sciences, Rutgers University, New Brunswick, NJ, USA. DONNA BLACKMAN is Research Geophysicist, Scripps Institution of Oceanography, La Jolla, CA, USA.

\begin{tabular}{|c|c|c|c|c|}
\hline Leg/Exp. ${ }^{*}$ & Year & Site \# & Location & Comment \\
\hline 158 & 1994 & 957 & $\begin{array}{l}\text { MAR } \\
26.14^{\circ} \mathrm{N}, 44.83^{\circ} \mathrm{W}\end{array}$ & TAG hydrothermal field, active high-temperature sulfide mound \\
\hline 169 & 1996 & $1035-1038$ & $\begin{array}{l}\text { Northern Juan de Fuca Ridge } \\
48.43^{\circ} \mathrm{N}, 128.68^{\circ} \mathrm{W} \\
\text { Escanaba Trough, } \\
\text { southern Gorda Ridge } \\
41.00^{\circ} \mathrm{N} 127.49^{\circ} \mathrm{W}\end{array}$ & $\begin{array}{l}\text { Sediment hosted, inactive massive sulfide deposit (Bent Hill) and ac- } \\
\text { tive hydrothermal field (Dead Dog); } 9 \text { holes to a maximum of } 404 \mathrm{~m} \\
\text { terminating in basalt, indicating that massive sulfide forms only a thin } \\
\text { veneer (5-15 m) over the sediment sequence along the faulted margin } \\
\text { of Central Hill }\end{array}$ \\
\hline 118,176 & $\begin{array}{l}1987 \\
1997\end{array}$ & 735 & $\begin{array}{l}\text { SWIR } \\
32.7^{\circ} S, 57.27^{\circ} \mathrm{E}\end{array}$ & $\begin{array}{l}\text { 1508-m-deep Hole 735B in the Atlantis Bank, Southwest Indian } \\
\text { Ridge (SWIR); this first deep hole in slow-spreading crust recovered } \\
\sim 86 \text { percent gabbroic rocks }\end{array}$ \\
\hline 179 & 1998 & 1105 & $\begin{array}{l}\text { SWIR } \\
32.7^{\circ} S, 57.28^{\circ} \mathrm{E}\end{array}$ & 158-m-deep Hole 1105A, $1.3 \mathrm{~km}$ east of Hole 735B (Atlantis Bank) \\
\hline 193 & $2000 / 01$ & $1188-1191$ & $\begin{array}{l}\text { Manus Basin } \\
03.72^{\circ} \mathrm{S}, 151.67^{\circ} \mathrm{E}\end{array}$ & $\begin{array}{l}13 \text { holes to a maximum of } 387 \text { meters below seafloor in PACManus } \\
\text { active high-temperature hydrothermal system, with minor sulfides } \\
\text { hosted in altered dacitic to rhyodacitic rocks }\end{array}$ \\
\hline 209 & 2003 & $\begin{array}{l}1268 \\
1270-1272 \\
1274 \\
1275\end{array}$ & $\begin{array}{l}\text { MAR } \\
14.85^{\circ} \mathrm{N}, 45.08^{\circ} \mathrm{W} \\
14.72^{\circ} \mathrm{N}, 44.89^{\circ} \mathrm{W} \\
15.04^{\circ} \mathrm{N}, 44.95^{\circ} \mathrm{W} \\
15.09^{\circ} \mathrm{N}, 44.97^{\circ} \mathrm{W} \\
15.65^{\circ} \mathrm{N}, 46.68^{\circ} \mathrm{W} \\
15.74^{\circ} \mathrm{N}, 46.90^{\circ} \mathrm{W}\end{array}$ & $\begin{array}{l}13 \text { holes in mantle peridotites and gabbroic rocks; } 209 \text {-m-deep } \\
\text { Hole } 1275 \mathrm{D} \text { in } 14.75^{\circ} \mathrm{N} \text { oceanic core complex, recovered gabbros } \\
\text { and troctolites }\end{array}$ \\
\hline 301 & 2004 & 1026,1301 & $\begin{array}{l}\text { Juan de Fuca Ridge } \\
47.76^{\circ} \mathrm{N}, 127.76^{\circ} \mathrm{W} \\
47.75^{\circ} \mathrm{N}, 127.77^{\circ} \mathrm{W}\end{array}$ & $\begin{array}{l}\text { Installation of seafloor observatory network on the eastern ridge } \\
\text { flank in preparation for long-tem monitoring and active hydrological } \\
\text { experiment }\end{array}$ \\
\hline 304,305 & $2004 / 05$ & 1309 & $\begin{array}{l}\text { MAR } \\
30.17^{\circ} \mathrm{N}, 42.12^{\circ} \mathrm{W}\end{array}$ & $\begin{array}{l}\text { Hole U1309D is the second deepest ( } 1415-\mathrm{m}) \text { gabbroic section recovered } \\
\text { in an oceanic core complex at a slow-spreading ridge }\end{array}$ \\
\hline $\begin{array}{l}206,309 \\
312\end{array}$ & $\begin{array}{l}2002 / 03 \\
2005\end{array}$ & 1256 & $\begin{array}{l}\text { Eastern Pacific, } \\
\text { Cocos Plate } \\
6.74^{\circ} \mathrm{N}, 91.93^{\circ} \mathrm{W}\end{array}$ & $\begin{array}{l}\text { 1255-m-deep Hole 1256D ( } 1005 \mathrm{~m} \text { in basement) reached the sheeted } \\
\text { dike/gabbro transition zone in } 15 \text { million-year-old, superfast-spreading } \\
\text { East Pacific Rise crust }\end{array}$ \\
\hline
\end{tabular}


basalts, and two serpentinized peridotite cobbles were trapped between two basaltic units in the core. The DSDP Leg 82 drilling plan was designed to address regional variations in basalt chemistry along the ridge axis. However, a few tens of meters of metamorphosed gabbro and many meters of pervasively serpentinized peridotite were recovered in three sites between $34^{\circ} 43^{\prime} \mathrm{N}$ and $38^{\circ} 56^{\prime} \mathrm{N}$. Clearly, the Penrose model didn't fit everywhere.

The stage was now set for future demonstrations that the oceanic crust can be highly variable in composition, structure, and thickness, especially at slow spreading rates. For crust formed at slow-spreading ridges, further drilling results (see next section) and seafloor observations support a model of composite crust comprised of gabbro intrusions embedded in serpentinized peridotites, locally but not systematically, overlain by sheeted dikes and basalts (e.g., Dick, 1989; Karson, 1990; Cannat, 1993; 1996; Lagabrielle et al., 1998). Crust formed at fast-spreading ridges appears to be more continuous and perhaps resembles the Penrose model more closely. Because of these apparent differences in crustal structure, drilling strategies differ: a single deep hole may be representative of continuous fast-spreading crust, whereas a series of offset drill holes may be required to adequately understand more complex areas.

\section{SLOW-SPREADING RIDGES,} COMPOSITE CRUST, AND OCEANIC CORE COMPLEXES

In 1986, mantle peridotites were intentionally drilled at a mid-ocean ridge for the first time during ODP Leg 109
(Site 670) on the west wall of the MidAtlantic Ridge median valley near $23^{\circ} 10^{\prime}$ N. Peridotites had just been identified on the seafloor during survey work done by the manned submersible Alvin in the same area. About $6.5 \mathrm{~m}$ of serpentinized harzburgite and dunite (olivinerich sub-types of peridotite) were recovered in a 92.5-m-deep hole. In the same area, south of the Kane Fracture Zone, $95 \mathrm{~m}$ of serpentinized peridotites were recovered from a 200-m-deep hole during ODP Leg 153. Ten years later, ODP Leg 209 returned to drill in the peridotite-rich area around the $15^{\circ} 20^{\prime} \mathrm{N}$ fracture zone on the Mid-Atlantic Ridge (Cannat et al., 1997). Thirteen holes at six sites along the spreading axis penetrated mantle peridotite and gabbroic rocks in proportions that were roughly $70 / 30$, similar to what was previously sampled on the seafloor in the same area. These findings were consistent with the hypothesis that slow-spreading oceanic crust in some cases consists of relatively small gabbro bodies intruded into mantle peridotite locally capped by erupted lavas (e.g., Cannat, 1993).

When plate tectonics pulls apart such heterogeneous crust, it doesn't break in a vertical plane. Long, deep-reaching but shallowly inclined faults seem to take up a lot of the plate spreading motion, exhuming and exposing lower crustal and mantle rocks in so-called core complexes. These oceanic core complexes form episodically, commonly near the ends of slow-spreading segments. Their domal cores commonly display spreading-parallel corrugations that are up to $100-\mathrm{m}$ high, several hundred meters wide, and tens of kilometers long. The most recent oceanic core complex to be drilled is the Atlantis Massif (Blackman et al., 2002) at the inside corner of the junction between the Mid-Atlantic Ridge and the Atlantis Fracture Zone at $30^{\circ} \mathrm{N}$ (Figure 2). The 1415.5-m-deep igneous section recovered at Site U1309 provides an exceptional record of magmatic accretion, tectonic exposure, and hydrothermal alteration in a slow-spreading environment. Lithology and deformation patterns in Hole U1309D are clearly distinct from those of the only other thick gabbro section, Hole 735B (Dick et al., 2000) on the Southwest Indian Ridge. This difference emphasizes the strong heterogeneity of oceanic crust formed at slow-spreading centers, even when sampled in what appear to be similar geodynamic settings.

A total of 16 holes ( $>10$-m deep) have been cored at eight different sites in four different oceanic core complexes (ODP Legs 118, 153, 176, 179, and 209; IODP Expeditions 304 and 305), and all recovered gabbroic sections. Early models for oceanic core complex formation were based on the hypothesis that a reduced magma supply is a critical factor in the development and longevity of strain along detachment faults. This hypothesis led to the general inference that oceanic core complexes represent periods of reduced magmatism at parts of slow-spreading segments. In contrast, ocean drilling results show that the borehole lithology is significantly different from the seafloor geology and support a working model in which relatively abundant magmatism, in otherwise relatively magma-poor areas, triggers the development of oceanic core complexes (Ildefonse et al., 2006). 

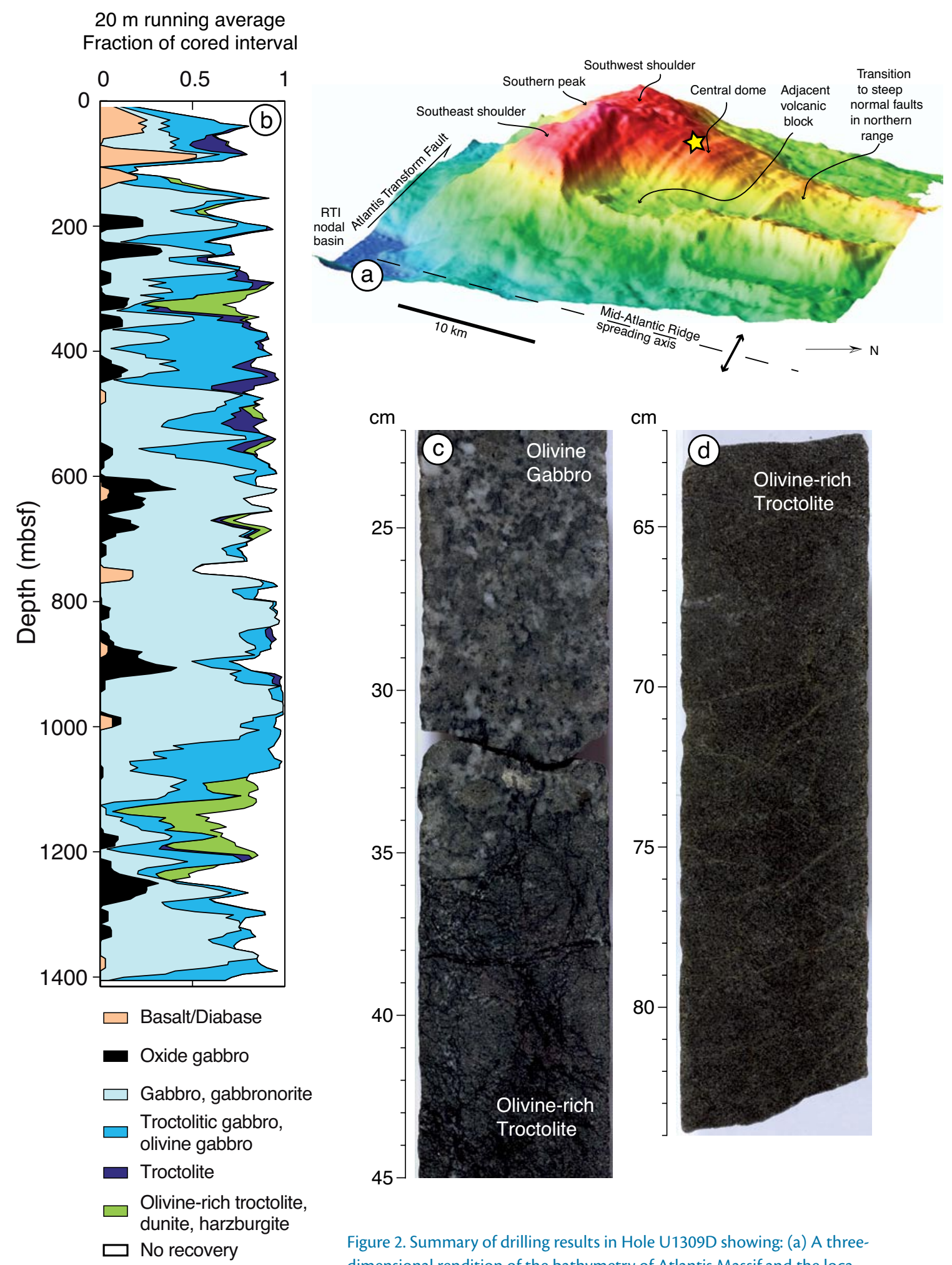

Figure 2. Summary of drilling results in Hole U1309D showing: (a) A threedimensional rendition of the bathymetry of Atlantis Massif and the location of Site U1309. (b) Downhole log indicating proportions of major rock types. (c,d) Core samples from $1100 \mathrm{~m}$ below seafloor showing typical olivine-rich troctolites. After Blackman et al., 2006 


\section{FAST-SPREADING RIDGES:}

\section{DRILLING A COMPLETE}

\section{SECTION OF OCEANIC CRUST}

At fast-spreading ridges, the oceanic crust is built by a constant influx of melt to the ridge-axis magma chamber (e.g., Sinton and Detrick, 1992). As a consequence, the structure of this crust is apparently much more homogeneous than at slow-spreading ridges, likely nearly continuous and close to the Penrose model (Conference Participants, 1972). This homogeneity, and the lack of heavily faulted, rough, high-relief topography common at slow-spreading ridges, has resulted in only a few places along the fast-spreading East Pacific Rise that allow access to deeper levels of the in situ crust. Such "tectonic windows" are found at places like Hess Deep (e.g., Francheteau et al., 1990), Pito Deep (e.g., Hekinian et al., 1996), or Endeavor Deep (e.g., Hooft et al., 1995), where previously formed Pacific crust is being ripped apart by a new spreading center. ODP

Leg 147 drilled upper mantle peridotites and upper crustal gabbros at two sites in a foundered tectonic block on the floor of Hess Deep.

Despite the success of such drilling in tectonic windows, deep drilling through an intact, complete section of the oceanic crust-the Mohole dream-remains a prime objective of the ocean drilling programs as it is the only way to answer some of the fundamental questions about how oceanic crust is formed. The deepest hole ever drilled in the oceanic crust, reaching 2111 meters below seafloor, is Hole 504B in the equatorial Pacific. Eight legs, starting with DSDP Leg 69 and ending 14 years later with ODP Leg 148, combined drilling, downhole logging, and necessary borehole cleanout operations, to penetrate $1836.5 \mathrm{~m}$ into pillow lavas and sheeted dikes before insurmountable technical problems forced further drilling to stop. The average recovery ( $\sim 20$ percent) was good enough to allow a complete study of the downhole alteration profile (Alt et al., 1996) and to demonstrate that, at site 504, the fundamental layer $2 / 3$ transition corresponds not to the dike/gabbro boundary, as had been assumed for years, but rather to an alteration front in the sheeted dikes.

The quest for total crustal penetration is not over and the lessons learned about deep drilling over the last 45 years have been put to good use. Initiated in 2002, near the end of ODP (Leg 206), as a dedicated deep drilling site, Hole 1256D was opened in 15-million-year-old crust that formed at the East Pacific Rise while it was spreading at a rate greater than $200 \mathrm{~mm} /$ year. Predictions were that this very high spreading rate would lead to the dike/gabbro boundary being formed close to the surface. Consistent with this prediction, Hole 1256D became the first hole to reach the base of the sheeted dike complex in December 2005 at the end of Expedition IODP 312 (Figure 3) (Wilson et al., 2006).

\section{HYDROTHERMAL SYSTEMS} AND MINERAL DEPOSITS

It isn't just going deep that has lead to amazing discoveries during the drilling programs. Just penetrating the seafloor takes scientists into the normally hidden third dimension of geological systems, opening up entirely new research areas. A good example is the investigation of seafloor hydrothermal systems (see also article by Tivey, this issue). Prior to the advent of drilling, hot-water circulation studies were limited to their seafloor and water-column manifestations, literally the "tip of the iceberg" of these systems that extend for kilometers beneath the seafloor and are the main means by which heat is extracted from the igneous seafloor. A typical seafloor hydrothermal system, based on studies in ophiolites (sections of former oceanic crust that have been raised onto dry land by plate-tectonic forces), begins at depth at the "reaction zone" near the top of a magma body where heat is exchanged with downwelling seawater. Axial magma chambers have been detected between 2 and $3 \mathrm{~km}$ depth at many sites on intermediate- and fast-spreading ocean ridges where the magma chamber may extend many kilometers along the spreading axis. One of the first magma chambers detected on the slow-spreading MidAtlantic Ridge was detected seismically about $3 \mathrm{~km}$ beneath the Lucky Strike hydrothermal field $\left(37^{\circ} 20^{\prime} \mathrm{N}, 32^{\circ} 15^{\prime} \mathrm{W}\right)$ where the magma chamber extends about $7 \mathrm{~km}$ along axis (Singh et al., 2006). Thermally expanded fluids rise buoyantly from this reaction zone, up through a zone of permeability that may be focused by intersecting faults. High-temperature fluids passing through this zone create a stockwork (rock containing ore veins) of alteration and mineralization, and may deposit a massive metal sulfide body. Metal-rich, high-temperature solutions (up to $400^{\circ} \mathrm{C}$ ) belch from mineralized chimneys on the seafloor.

ODP has drilled into three types of seafloor hydrothermal systems:

(1) hydrothermal systems that concentrate massive sulfide bodies hosted in 


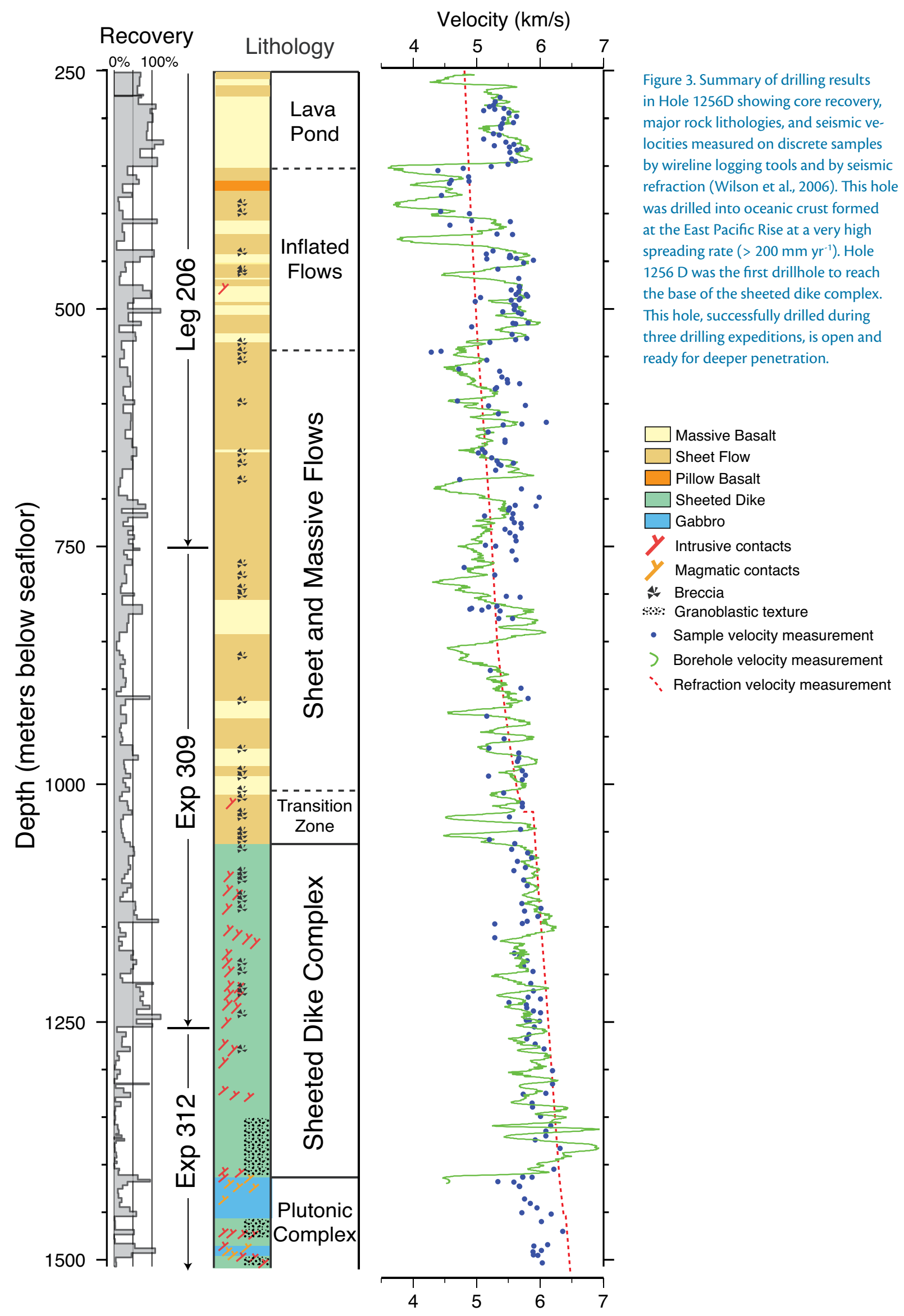



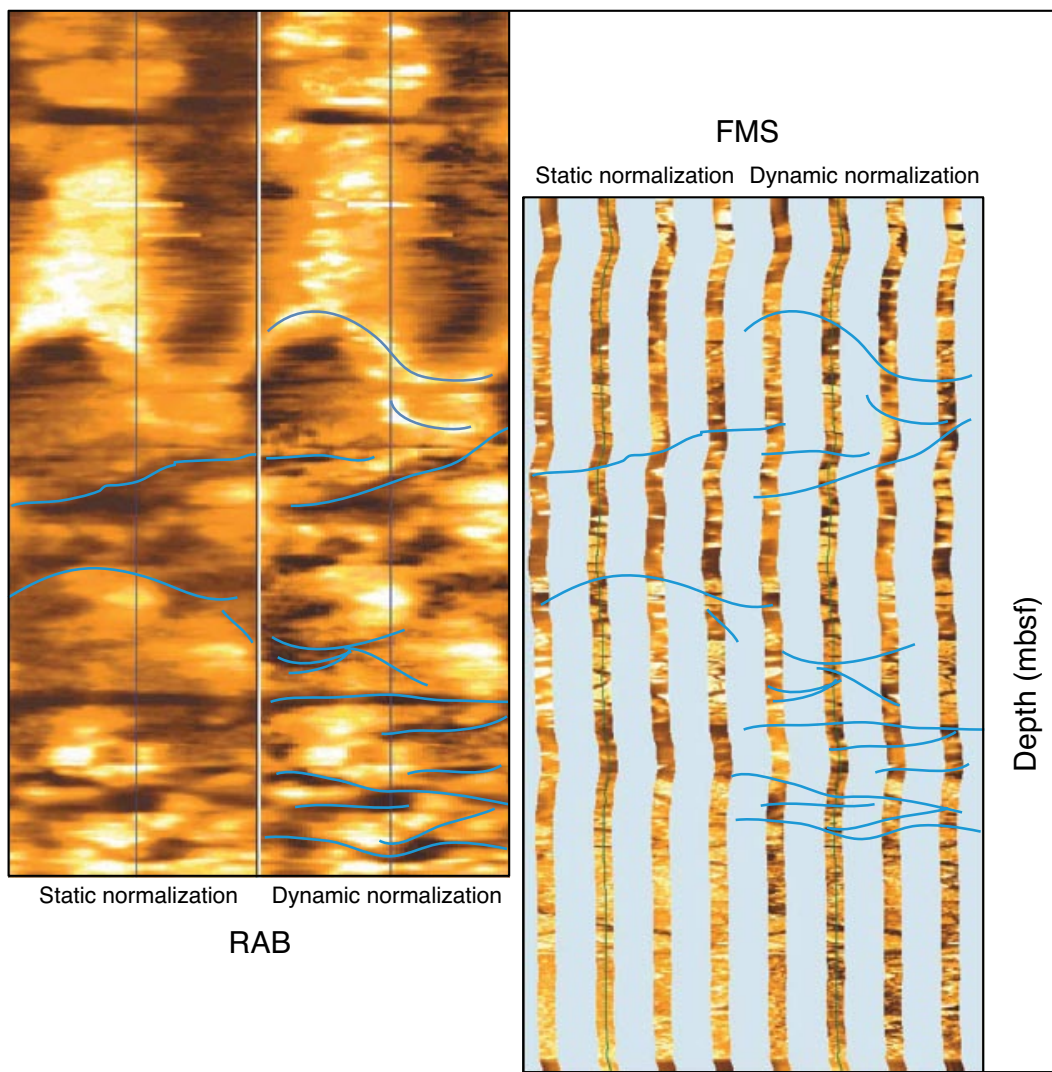

Figure 4. A comparison between logging-while-drilling Resistivity-At-the-Bit (RAB) (logging data collected while the hole is being drilled) and wireline log data (logging data collected after the hole has been drilled) from the first ODP deployment of the RAB tool in Hole 1189 C (ODP Leg 193). The measurements provide images of the borehole wall (left and center) and log curves of electrical resistivity (right). The RAB data (image and

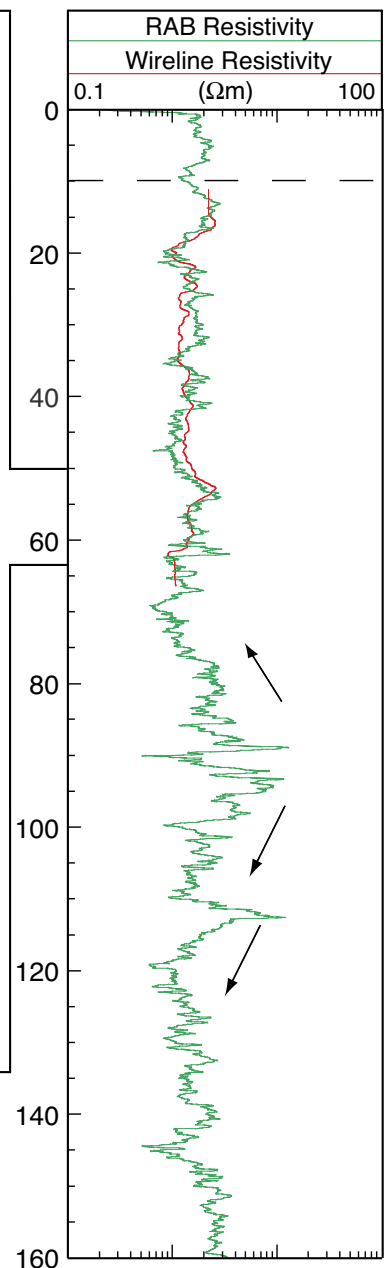
resistivity) show fracture patterns and alteration trends (denoted by arrows) that may be indicative of hydrothermal fluid flow along fractures. The wireline logging data were collected only in the upper $65 \mathrm{~m}$ because of a hole obstruction, emphasizing the value of obtaining logging-while-drilling data before deterioration of borehole conditions. Various features (including fractures) marked by contrasted electrical conductivities (underlined in blue) correlate well between the full $360^{\circ}$ coverage RAB and the higher-resolution ( $<2$ percent borehole coverage) Formation MicroScanner (FMS)-oriented images. Because of relatively low core recovery, the logging-while-drilling logs provide the only continuous record of the lithostratigraphic sequences drilled in the Manus Basin. Modified from Binns et al., 2002

basaltic (mafic—-high in magnesium and iron) volcanic rocks of the oceanic crust (Transatlantic Geotraverse [TAG] at the Mid-Atlantic Ridge drilled during Leg 158); (2) hydrothermal systems that concentrate massive sulfide bodies hosted in dacitic-rhyolitic (felsic—high in silica and feldspar) volcanic rocks (PACManus in the Manus back-arc basin, western Pacific Ocean, drilled during Leg 193); and (3) hydrothermal systems hosted in sediments (Escanaba Trough, Gorda Ridge, and Middle Valley, Juan de Fuca Ridge in the Northeast Pacific Ocean, drilled during Legs 139 and 169). Drilling into massive sulfides and volcanic rocks is technically feasible but difficult, and core recovery is limited.
In this context, downhole geophysical measurements and imaging are particularly important for depicting lithology and physical-property variations where core is missing. At PACManus, advances in logging provided continuous imagery of the section penetrated using Resistivity-At-the-Bit, the Formation MicroScanner, and other methods 


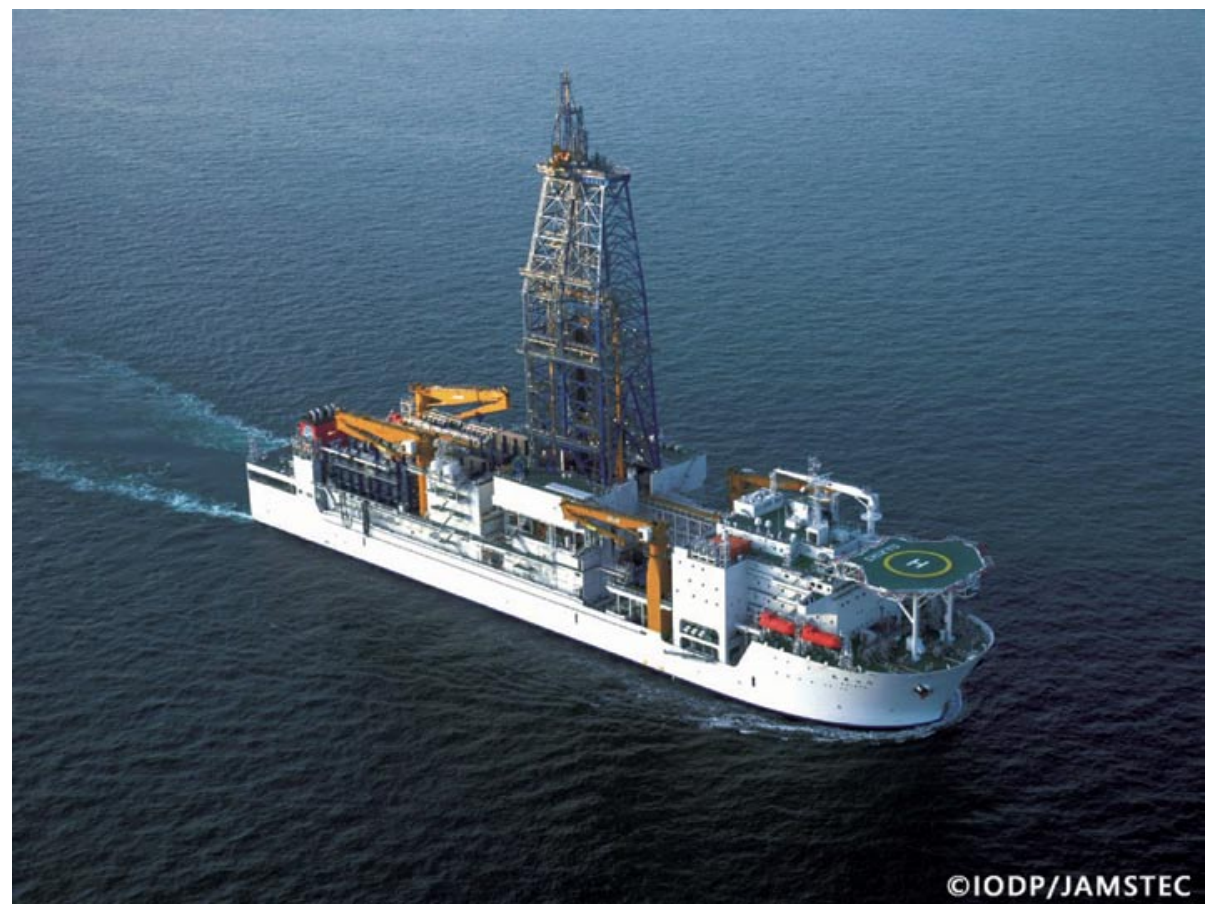

Figure 5. Oceanographic Drilling Vessel Chikyu sailing in Tokyo Bay. Chikyu is 210-m-long, can accommodate 150 people, and will operate for IODP at the end of 2007. Thanks to the riser drilling technology, Chikyu is expected to drill much deeper than conventional nonriser vessels used so far in scientific ocean drilling. Complete information is available online at www.jamstec.go.jp/ chikyu/eng/.

(Figure 4). The maximum penetration achieved so far is about 500 meters below the seafloor in sediments that host the inactive Bent Hill massive sulfide body in Middle Valley. This depth is far short of the reaction zone, which is a distant goal of drilling seafloor hydrothermal systems. Immediate goals are to determine heat and chemical exchanges in the hydrothermal systems, investigate the subseafloor biosphere, and characterize the mineralization as an analog of ancient volcanogenic massive sulfide deposits and sedimentary exhalative deposits (ore deposit formed through the precipitation of minerals out of hydrothermal fluids through contact with cold seawater) that are economically important as sources of copper, zinc, silver, gold, and other elements where accessible on land.
WHAT'S NEXT? DRILLING MORE, DRILLING DEEP, AND LONG-TERM BOREHOLE

\section{MONITORING}

We will soon celebrate 40 years of scientific ocean drilling. Since the early days of DSDP, considerable progress has been made in understanding the architecture of the oceanic crust and related midocean ridge accretion and alteration processes. Nevertheless, we still know very little. Fewer than 20 basement holes are deeper than $200 \mathrm{~m}$ and only four have exceeded a depth of $1 \mathrm{~km}$. There is a long way to go to reach the Moho and to fully understand mid-ocean ridge dynamics. Potential future directions of the ongoing IODP include:

- Drilling deeper at some sites where part of the history is already revealed. Two of the four existing deep holes
(U1309D in the Atlantis Massif at the slow-spreading Mid-Atlantic Ridge, and 1256D in the superfast spreading East Pacific Rise crust) are still open and ready to be deepened. These holes are probably priority targets for the future, together with some other known sites (e.g., Hole 735B in the Atlantis Bank, Southwest Indian Ridge). Drilling deep requires tools that have so far not been available to the scientific community; the road to the few very deep holes drilled so far was very roughly paved. The new drilling vessel Chikyu (Figure 5) will soon provide IODP with riser drilling technology, which should allow us to penetrate more deeply and eventually to penetrate the base of the crust into the uppermost mantle in boreholes that are roughly $6-\mathrm{km}$ deep. In its 
present configuration, Chikyu will not be able to drill at Site 1256 because the seafloor exceeds its water-depth capability for riser drilling $(2500 \mathrm{~m})$. The extension of the riser to $4000 \mathrm{~m}$ or even $4500 \mathrm{~m}$ is a goal hoped for by the mid-ocean ridge research community.

- Drilling new sites in different settings will provide further insight on the variability of the oceanic crust. Other oceanic core complexes are already targeted in IODP drilling proposalsthe Kane core complex at the MidAtlantic Ridge (Tucholke et al., 1998) and the Godzilla core complex in the Parece Vela back-arc basin (Ohara et al., 2001). Ultra-slow spreading centers, such as the Gakkel Ridge (Dick et al., 2003) or certain portions of the Southwest Indian Ridge (Dick et al., 2003; Cannat et al., 2006), constitute the magma-poor end-member of mid-ocean ridges and therefore likely provide an ideal spot to drill mantle peridotites.

- Drilling of hydrothermal systems hosted in ultramafic rocks, such as the Rainbow Hydrothermal Field on the Mid-Atlantic Ridge (Fouquet et al., 1997), and drilling an assemblage of large massive sulfide mounds from young-hot to old-cold spanning over 100,000 years in the TAG hydrothermal field, will allow us to determine the evolution of a seafloor hydrothermal system from origin to extinction (Rona et al., 1993). Mid-ocean ridges, and hydrothermal systems in particular, are a privileged location for deep biosphere development; investigation of the subseafloor biosphere is an especially important and challenging theme of IODP as a major component of examining the role of microbes in global biogeochemical processes (e.g., Staudigel and Furnes, 2004).

- Another fundamental IODP goal is to deploy borehole instruments capable of acquiring time series of physical properties of the oceanic crust and to sample circulating fluids. At mid-ocean ridges, such deep-sea observatories allow the documentation of crustal hydrological properties (see review of "CORK” design and operation during ODP in Becker and Davis [2005]). A network of seafloor observatories has recently been set up (IODP Expedition 301) on the eastern flank of the Juan de Fuca Ridge. This network is designed to conduct active, multidisciplinary experiments over time scales of minutes to years and length scales of meters to kilometers. Operations will include offset seismic experiments, long-term monitoring, and cross-hole testing (Fisher et al., 2005). Fluid flow through the oceanic crust provides the main mechanism for heat and chemical exchange between the crust and the ocean, and supplies nutrients to organisms living at and below the seafloor. Data from seafloor observatories will shed new light on the subseafloor hydrogeological dynamics of the ridge, especially in relation to magmatic and tectonic activity, and on the related development of the subseafloor biosphere.

These potential future directions of the IODP address InterRidge's Deep Earth Sampling objectives: to continue to drill active hydrothermal systems and young oceanic crust to determine the interrelated magmatic and tectonic evolution of these systems, to elucidate the nature of the subseafloor biosphere, and to achieve total penetration of oceanic crust (Atlantic and Pacific) within about 20 years. Achieving these goals will fulfill the InterRidge mission to promote interdisciplinary, international, collaborative, and multidisciplinary studies of oceanic spreading centers. ⿷匚

\section{REFERENCES}

Alt, J.C., C. Laverne, D.A. Vanko, P. Tartarotti, D.A.H. Teagle, W. Bach, E. Zuleger, J. Erzinger, J. Honnorez, P.A. Pezard, K. Becker, M.H. Salisbury, and R.H. Wilkens. 1996. Hydrothermal alteration of a section of upper oceanic crust in the eastern equatorial Pacific: A synthesis of results from Site 504 (DSDP Legs 69, 70, and 83, and ODP Legs $111,137,140$, and 148). Pp. 417-434 in Proceedings of the Ocean Drilling Program, Scientific Results, v. 148, J.C. Alt, H. Kinoshita, L.B. Stokking, and P.J. Michael, eds. Ocean Drilling Program, College Station, TX.

Bascom, W.N. 1961. A Hole in the Bottom of the Sea: The Story of the Mohole Project. Doubleday and Company, Inc., Garden City, New York, 352 pp.

Becker, K., and E.E. Davis. 2005. A review of CORK designs and operations during the Ocean Drilling Program. In: Proceedings of the Integrated Ocean Drilling Program, v. 301, A.T. Fisher, T. Urabe, A. Klaus, and the Expedition 301 Scientists, eds. Integrated Ocean Drilling Program Management International, Inc., College Station TX, doi:10.2204/iodp.proc.301.104.2005.

Binns, R.A., F.J.A.S. Barriga, D.J. Miller, et al. 2002. Proceedings of the Ocean Drilling Program, Initial Reports, v. 193. Ocean Drilling Program, College Station, TX. [Online] Available at: http://wwwodp.tamu.edu/publications/193_IR/193ir.htm (last accessed November 8, 2006).

Blackman, D.K., J.A. Karson, D.S. Kelley, J.R. Cann, G.L. Fruh-Green, J.S. Gee, S.D. Hurst, B.E. John, J. Morgan, S.L. Nooner, D.K. Ross, T.J. Schroeder, and E.A. Williams. 2002. Geology of the Atlantis Massif (Mid-Atlantic Ridge, $30^{\circ} \mathrm{N}$ ): Implications for the evolution of an ultramafic oceanic core complex. Marine Geophysical Research 23:443-469.

Blackman, D.K., B. Ildefonse, B.E. John, Y. Ohara, D.J. Miller, C.J. MacLeod, and the Expedition 304/305 Scientists. 2006. Proceedings of the Integrated Ocean Drilling Program, 304/305. Integrated Ocean Drilling Program Management International, Inc., College Station TX, doi:10.2204/iodp. proc.304305.2006.

Cannat, M. 1993. Emplacement of mantle rocks in the seafloor at mid-ocean ridges. Journal of Geophysical Research 98:4,163-4,172. 
Cannat, M., Y. Lagabrielle, H. Bougault, J. Casey, N. de Coutures, L. Dmitriev, and Y. Fouquet. 1997. Ultramafic and gabbroic exposures at the MidAtlantic Ridge: Geological mapping in the $15^{\circ} \mathrm{N}$ region. Tectonophysics 279:193-213.

Cannat, M., D. Sauter, V. Mendel, E. Ruellan, K. Okino, J. Escartin, V. Combier, and M. Baala. 2006. Modes of seafloor generation at a melt-poor ultraslow-spreading ridge. Geology 34:605-608.

Conference Participants. 1972. Penrose field conference on ophiolites. Geotimes 17:24-25.

Constantin, M., R. Hekinian, D. Bideau, and R. Hebert. 1996. Construction of the oceanic lithosphere by magmatic intrusions: Petrological evidence from plutonic rocks formed along the fast-spreading East Pacific Rise. Geology 24:731-734.

Dick, H.J.B. 1989. Abyssal peridotites, very slow spreading ridges and ocean ridge magmatism. Pp. 71-105 in Magmatism in the Ocean Basins. A.D. Saunders and M.J. Norry, eds, Geological Society of London Special Publications 42.

Dick, H.J.B., J. Erzinger, L.B. Stokking, et al., 1992. Proceedings of the Ocean Drilling Program, Initial Reports, 140. Ocean Drilling Program, College Station, TX.

Dick, H.J.B., J. Lin, and H. Schouten. 2003. An ultraslow-spreading class of ocean ridge. Nature 426:405-412.

Dick, H.J.B., J.H. Natland, J.C. Alt, W. Bach, D. Bideau, J.S. Gee, S. Haggas, J.G.H. Hertogen, G. Hirh, P.M. Holm, B. Ildefonse, G.J. Iturrino, B.E. John, D.S. Kelley, E. Kikawa, A. Kingdon, P.J. LeRoux, J. Maeda, P.S. Meyer, J.D. Miller, H.R. Naslund, Y. Niu, P.T. Robinson, J. Snow, R.A. Stephen, P.W. Trimby, H.U. Worm, and A. Yoshinobu. 2000. A long in-situ section of the lower ocean crust: Results of ODP Leg 176 drilling at the Southwest Indian Ridge. Earth and Planetary Science Letters 179:31-51.

Fisher, A.T., C.G. Wheat, K. Becker, E.E. Davis, H. Jannasch, D. Schroeder, R. Dixon, T.L. Pettigrew, R. Meladrum, R. MacDonald, M. Nielsen, M. Fisk, J. Cowen, W. Bach, and K. Edwards. 2005. Scientific and technical design and deployment of long-term, subseafloor observatories for hydrogeologic and related experiments, IODP Expedition 301, eastern flank of Juan de Fuca Ridge. In: Proceedings of the Integrated Ocean Drilling Program, v. 301, A.T. Fisher, T. Urabe, A. Klaus, and the Expedition 301 Scientists. eds. Integrated Ocean Drilling Program Management International, Inc., College Station TX, doi:10.2204/iodp. proc.301.103.2005.

Fouquet, Y., J.L. Charlou, H. Ondréas, J. RadfordKnoery, J.P. Donval, E. Douville, R. Apprioual, P. Cambon, H. Pellé, J.Y. Landuré, A. Normand, E. Ponsevera, C. German, L. Parson, F. Barriga, I. Costa, J. Relvas, and A. Ribeiro. 1997. Discovery and first submersible investigations on the Rainbow Hydrothermal Field on the MAR $\left(36^{\circ} 14 \mathrm{~N}\right)$.
Eos, Transactions, American Geophysical Union, Fall Meeting Supplement, Abstract V51E-05.

Francheteau, J., R. Armijo, J.L. Cheminée, R. Hekinian, P. Lonsdale, and N. Blum. 1990. 1 My East Pacific Rise oceanic crust and uppermost mantle exposed by rifting in Hess Deep (equatorial Pacific Ocean). Tectonophysics 151:1-26.

Greenberg, D.S. 1971. Mohole: Geopolitical fiasco. Pp. 343-348 in Understanding the Earth. I.G. Gass, P.J. Smith, R.C.L. Wilson, and the Open University, eds, MIT Press, Cambridge, MA.

Hekinian, R., J. Francheteau, R. Armijo, J.P. Cogne, M. Constantin, J. Girardeau, R. Hey, D.F. Naar, and R. Searle. 1996. Petrology of the Easter microplate region in the South Pacific. Journal of Volcanology and Geothermal Research 72:259-289.

Hooft, E., M. Kleinrock, and C. Ruppel. 1995. Rifting of Oceanic-Crust at Endeavor-Deep on the Juan-Fernandez Microplate. Marine Geophysical Researches 17:251-273.

Ildefonse, B., D. Blackman, B.E. John, Y. Ohara, D.J. Miller, C.J. MacLeod, and IODP Expeditions 304-305 Scientific Party. 2006. A revised model of oceanic core complex structure? Indications from IODP Expeditions 304-305, Mid-Atlantic Ridge, $30^{\circ} \mathrm{N}$, and previous ocean drilling results. Geophysical Research Abstracts 8:05723; SRefID:1607-7962/gra/EGU06-A-05723.

Karson, J.A. 1990. Seafloor spreading on the MidAtlantic Ridge: Implications for the structure of ophiolites and oceanic lithosphere produced in slow-spreading environments. Pp. 125-130 in Ophiolites and Oceanic Crustal Analogues: Proceedings of the Symposium "Troodos 1987". J. Malpas, E.M. Moores, A. Panayiotou, and C. Xenophontos, eds, Geological Survey Department, Nicosia, Cyprus.

Lagabrielle, Y., D. Bideau, M. Cannat, J.A. Karson, and C. Mevel. 1998. Ultramafic-mafic plutonic rock suites exposed along the Mid-Atlantic Ridge $\left(10^{\circ} \mathrm{N}-30^{\circ} \mathrm{N}\right)$. Symmetrical-asymmetrical distribution and implications for seafloor spreading processes. Pp. 153-176 in Faulting and Magmatism at Mid-Ocean Ridges. W.R. Buck, P.T. Delaney, J.A. Karson, and Y. Lagabrielle, eds, Geophysical Monograph 106, American Geophysical Union, Washington, DC.

Lill, G., and W. Bascom. 1959. A bore-hole to the Earth's mantle: AMSOC Mohole. Nature 184:140-144.

Macdonald, K.C. 1998. Linkages between faulting, volcanism, hydrothermal activity and segmentation on fast spreading centers. Pp. 27-58 in Faulting and Magmatism at Mid-Ocean Ridges. W.R. Buck, P. T. Delaney, J. A. Karson, and Y. Lagabrielle, eds, Geophysical Monograph 106, American Geophysical Union, Washington, DC.

Ohara, Y., T. Yoshida, Y. Kato, and S. Kasuga. 2001. Giant megamullion in the Parece Vela Backarc Basin. Marine Geophysical Research 22:47-61. Pardee, D.R., R.N. Hey, and F. Martinez. 1998. Cross- sectional areas of mid-ocean ridge axes bounding the Easter and Juan Fernandez microplates. $\mathrm{Ma}$ rine Geophysical Research 20:517-531.

Rona, P. A., M.D. Hannington, C.V. Raman, G. Thompson, M.K. Tivey, S.E. Humphris, C. Lalou, and S. Petersen. 1993. Active and relict sea-floor hydrothermal mineralization at the TAG hydrothermal field, Mid-Atlantic Ridge. Economic Geology 88:1,987-2,013.

Shor, E.N. 1985. A chronology from Mohole to JOIDES. Pp. 391-399 in Geologists and Ideas: A History of North American Geology. E.T. Drake and W.M. Jordan, eds, Geological Society of America Special Publication 4, Boulder, CO.

Singh, S.C., W.C. Crawford, H. Carton, T. Seher, V. Combier, M. Cannat, J.P. Canales, D. Dusunur, J. Escartin, and J.M. Miranda. 2006. Discovery of a magma chamber and faults beneath a Mid-Atlantic Ridge hydrothermal field. Nature 442:1029-1032.

Sinton, J.M., and R.S. Detrick. 1992. Mid-ocean ridge magma chambers. Journal of Geophysical Research 97:197-216.

Staudigel, H., and H. Furnes. 2004. Microbial mediation of oceanic crust alteration. Pp. 606-624 in Hydrogeology of the Oceanic Lithosphere. E.E. Davis and H. Elderfield, eds, Cambridge University Press, Cambridge, UK.

Tucholke, B.E., and J. Lin. 1994. A geological model for the structure of ridge segments in slow spreading ocean crust. Journal of Geophysical Research 99:11,937-11,958.

Tucholke, B.E., J. Lin, and M.C. Kleinrock. 1998. Megamullions and mullion structure defining oceanic metamorphic core complexes on the midAtlantic ridge. Journal of Geophysical Research 103:9,857-9,866.

Wilson, D.S., D.A.H. Teagle, J.C. Alt, N.R. Banerjee, S. Umino, S. Miyashita, G.D. Acton, R. Anma, S.R. Barr, A. Belghoul, J. Carlut, D.M. Christie, R.M. Coggon, K.M. Cooper, C. Cordier, L. Crispini, S.R. Durand, F. Einaudi, L. Galli, Y.J. Gao, J. Geldmacher, L.A. Gilbert, N.W. Hayman, E. HerreroBervera, N. Hirano, S. Holter, S. Ingle, S.J. Jiang, U. Kalberkamp, M. Kerneklian, J. Koepke, C. Laverne, H.L.L. Vasquez, J. Maclennan, S. Morgan, N. Neo, H.J. Nichols, S.H. Park, M.K. Reichow, T. Sakuyama, T. Sano, R. Sandwell, B. Scheibner, C.E. Smith-Duque, S.A. Swift, P. Tartarotti, A.A. Tikku, M. Tominaga, E.A. Veloso, T. Yamasaki, S. Yamazaki, and C. Ziegler. 2006. Drilling to gabbro in intact ocean crust. Science 312:1,016-1,020. 